\title{
WOOD DENSITY OF CLONES OF Eucalyptus urophylla x Eucalyptus grandis IN DIFFERENT CONDITIONS OF GROWTH
}

\author{
Renata Mauri ${ }^{1}$, José Tarcísio da Silva Oliveira ${ }^{2}$, Mário Tomazello Filho ${ }^{3}$, Antônio Marcos Rosado ${ }^{4}$, \\ Juarez Benigno Paes ${ }^{2}$, Natalino Calegario ${ }^{5}$ \\ ${ }^{1}$ Federal University of Lavras, PhD Program in Wood Science and Technology, Lavras, Minas Gerais, Brazil - \\ renatamauri@yahoo.com.br \\ ${ }^{2}$ Federal University of Espirito Santo, Department of Forest Engineering, Jerônimo Monteiro, Espirito Santo, Brazil - \\ jtsilva@npd.ufes.br; jbp2@uol.com.br \\ ${ }^{3}$ Superior School of Agriculture Luiz de Queiroz ofUniversity of São Paulo, Department of Forest Sciences, Piracicaba, São Paulo, \\ Brazil - mtomazel@esalq.usp.br \\ ${ }^{4}$ CENIBRA (Celulose Nipo Brasileira), Belo Oriente, Minas Gerais, Brasil- antonio.rosado@ cenibra.com.br \\ ${ }^{5}$ Federal University of Lavras, Department of Forest Sciences, Lavras, Minas Gerais, Brazil - calegari@ dcf.ufla.br
}

Received for publication: 29/10/2013 - Accepted for publication: 09/05/2014

\begin{abstract}
Variations in the growth site of trees have influence on the internal structure of the trunk. Considering this fact, this study investigated influence of the characteristics of the growth site on wood specific gravity of two clones of Eucalyptus urophyllax Eucalyptus grandis, approximately six years old, growing in different altitudes and topographies. Furthemore, two methods of sampling of the wood specific gravity were studied, for comparison purpose. Results showed that wood specific gravity underwent variations between growth conditions andtrends in wood specific gravity variations, compared between growth conditions, were the same regardless of the clone. With relation to sampling method, the wedge was more appropriate for determination of wood specific gravity, in order to extrapolate the disc density. These results provide tools to forestry companies about consolidation of genetic material and its behavior in different growth conditions, to attend wood quality requirements.
\end{abstract}

Keywords: Eucalypt; wood quality;topography; altitude.

\section{Resumo}

Densidade do lenho de clones de Eucalyptus urophylla x Eucalyptus grandis em diferentes condições de crescimento. As variações nas características do local de crescimento das árvores apresentam influência na estrutura interna do tronco. Diante deste fato, foi estudada a influência das características do local de crescimento na densidade básica da madeira de dois clones de EucalyptusurophyllaxEucalyptusgrandis, com aproximadamente seis anos de idade que cresceram emaltitudes e topografias diferentes. Além disso, estudou-se duas formas de amostragem da densidade básica na árvore para fins de comparações. Por meio dos resultados pode-seobservar que a densidade básica da madeira sofreu variações nas diferentes condições de crescimento e que as tendências de variações na densidade básica da madeira, frente às condições de crescimento, foram as mesmas independentemente do clone. Em relaçãoao método de amostragem,a cunha mostrou-se mais apropriada para determinação da densidade básica da madeira para fins de extrapolação da densidade do disco.Estes resultados fornecem subsídios para as empresas do setor florestal no que diz respeito à consolidação de material genético e seu comportamento em diferentes condições de crescimento para atender suas demandas de qualidade de madeira.

Palavras-chave:Eucalipto; qualidade de madeira;topografia; altitude.

\section{INTRODUCTION}

Brazil is a country with great forestry vocation due to its climate and soil conditions. The country includes approximately 7.19 million of hectares of planted forests, mainly formed by genera Eucalyptus and Pinus, which occupy around 6.66 million of hectares, divided in $76.6 \%$ Eucalyptus and $23.4 \%$ Pinus (ASSOCIAÇÃO BRASILEIRA DE PRODUTORES DE FLORESTAS PLANTADAS (ABRAF), 2013).

FLORESTA, Curitiba, PR, v. 45, n. 1, p. 193 - 202, jan. / mar. 2015.

Mauri, R. et al.

ISSN eletrônico 1982-4688 / ISSN impresso 0015-3826 
The establishment of the genus Eucalyptus occurred mainly due to its rapid growth and edaphoclimatic adaptability to a wide range of sites. Among the various species of commercially planted Eucalyptus, interspecific hybrids Eucalyptus urophylla x Eucalyptus grandis stand out in the Brazilian forestry scenery for their rapid growth, with harvesting cycles from 6 to 7 years (BASSA et al., 2007). However, saying that a species is adaptable to a wide range of sites does not necessarily mean that the species, planted in different conditions, will develop with the same physical and anatomic characteristics, and consequently with the desired quality standards.

As important as prediction of volume, prediction of produced wood quality is essential for a forest stand site. Among the various wood quality indexes used in the forestry industry, basic density has great importance for being widely used in the different industries of the sector, and for being one of the wood characteristics that best express its quality in the industrial transformation. Basic density can also be used to define the harvesting age, due to the increase in value over the years.

Nowadays, existing plantations in the country are basically there to provide raw matter to industries producing cellulose, paper, fiber boards, charcoal, wood, solid products in round and sawn shapes, among others. For the production of any wood-derived product, raw matter should be as much uniform as possible. For this reason, many studies were conducted to clarify longitudinal and radial variations of wood (BARRICHELO et al., 1983; TOMAZELLO FILHO,1985; SHIMOYAMA, 1991; BAPTISTA et al., 2003; OLIVEIRA et al., 2005; GONÇALVES, 2006; SILVA et al., 2004; TREVISAN et al., 2008; TRIANOSKI et al., 2013 and many others), and basic density variations, due to growth conditions (interaction between genotype and environment), however these last ones sometimes come to different conclusions (MORA et al.; 1978; RIBEIRO; ZANI FILHO, 1993; BRASIL; VEIGA, 1994). Even so it is possible to say that climate, together with genetics of the species, has great influence on structure of the xylem (METCALFE; CHALK, 1950; BAAS, 1973).

Baas (1973) and Metcalfe \& Chalk (1983), report that one of the biggest challenges in studying influence of environmental factors on anatomic diversity of wood, is to establish a firm link between which are the anatomic changes due to environmental factors and which are the hereditary characteristics of the species. However, for commercial species of the genus Eucalyptus, this difficulty was bypassed by the emerging of cloning technique.

If reactions of plant growth to local growth conditions, for example topographic variations, were better understood, it would not only be possible to provide a base to determine the best species for plantation, but also to predict quality of the wood produced. In this study, the hypothesis was that clones planted in different topographic and altitude conditions might present variations in basic wood density due to environment influence. At that, this study had the objective to assess comparatively the wood density behavior of trees planted in in different growth conditions. Besides, to assess the different sampling methods performed on the trunk, to determine its density.

\section{MATERIAL AND METHODS}

Woods from two interspecific clonal hybrids of Eucalyptus urophylla $\mathrm{x}$ Eucalyptus grandis were used, provided by commercial plantations of the company CENIBRA (Celulose Nipo-Brasileira), defined in this work as clone 1 and clone 2, approximatively six years old and grown in distinct altitudes and topographies of Minas Gerais State, thus totalizing eight treatments.

For each treatment were used five replications, totalizing 40 trees. Figure 1 shows the mentioned treatments. 


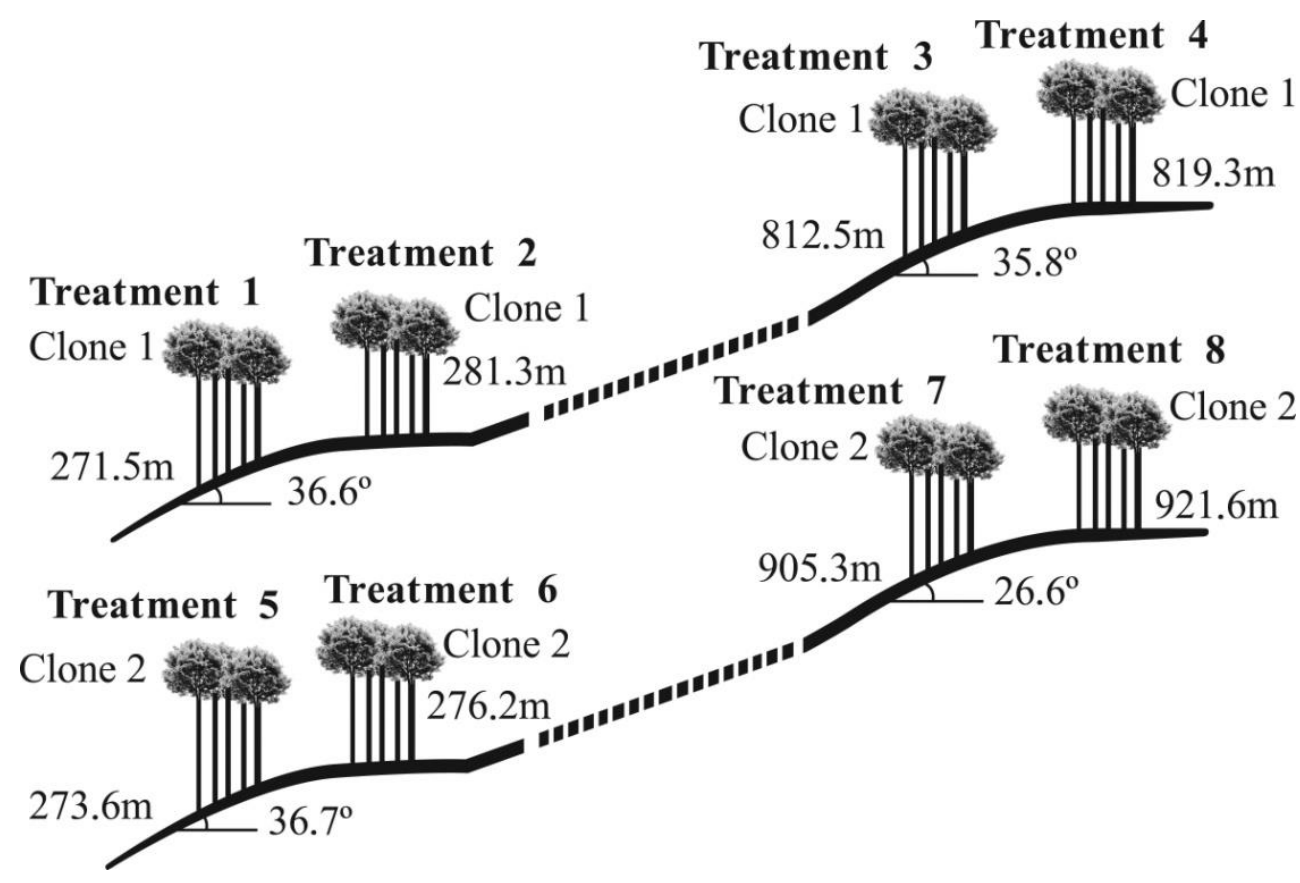

Figure 1. Treatments used in this study.

Figura 1. Tratamentos realizados neste estudo.

In all the planting conditions, the same north face was exposed to sun. In table 1, treatments used in the study are descirbed.

Table 1. Climatic characterizations of crops of the sampled clones.

Tabela 1. Caracterização climática das plantações dos dois clones amostrados.

\begin{tabular}{|c|c|c|c|c|c|c|c|c|}
\hline \multirow[b]{2}{*}{ Clone } & \multirow{2}{*}{$\begin{array}{c}\text { Growth } \\
\text { condition }^{1}\end{array}$} & \multicolumn{3}{|c|}{ Temperature $\left({ }^{\circ} \mathrm{C}\right)$} & \multirow{2}{*}{$\begin{array}{c}\text { Rainfall } \\
\text { (mm) }\end{array}$} & \multirow{2}{*}{$\begin{array}{c}\text { Hydric } \\
\text { deficit }^{2} \\
(\mathrm{~mm})\end{array}$} & \multirow{2}{*}{$\begin{array}{c}\text { Photosynthetic } \\
\text { ally active } \\
\text { radiation } \\
\left(\mathrm{mmol} / \mathrm{m}^{2} / \mathrm{s}\right)\end{array}$} & \multirow{2}{*}{$\begin{array}{c}\text { Type of } \\
\text { soil }\end{array}$} \\
\hline & & Min & $\operatorname{Max}$ & Mean & & & & \\
\hline \multirow[t]{4}{*}{1} & Low/Inclined & 18.9 & 31.00 & 24.50 & 1229.80 & 299.00 & 33442.00 & $\mathrm{CXbd}^{4}$ \\
\hline & Low/Plain & 18.9 & 31.00 & 24.50 & 1229.80 & 299.00 & 33442.00 & $\mathrm{CXbd} 3^{5}$ \\
\hline & High/Inclined & 15.00 & 24.30 & 20.20 & 1280.30 & 96.00 & 29671.00 & CXbd1 \\
\hline & High/Plain & 15.00 & 24.30 & 20.20 & 1280.30 & 96.00 & 29671.00 & CXbd1 \\
\hline \multirow[t]{4}{*}{2} & Low/Inclined & 18.9 & 31.00 & 24.50 & 1229.80 & 299.00 & 33442.00 & CXbd1 \\
\hline & Low/Plain & 18.9 & 31.00 & 24.50 & 1229.80 & 299.00 & 33442.00 & CXbd3 \\
\hline & High/Inclined & 15.00 & 24.30 & 20.20 & 1280.30 & 96.00 & 29671.00 & CXbd1 \\
\hline & High/Plain & 15.00 & 24.30 & 20.20 & 1280.30 & 96.00 & 29671.00 & CXbd1 \\
\hline
\end{tabular}

"Growth condition corresponds to "Altitude/Topography", being altitude $<281.3 \mathrm{~m}$ defined as low region and altitude $>812.5 \mathrm{~m}$ defined as high region; and topography : $0^{\circ}$ defined as plain, topography $>26.6^{\circ}$ defined as inclined. ${ }^{2}$ To calculate hydric deficit, terrain inclination was considered. ${ }^{3}$ To calculate the photosynthetically active radiation, inclination of terrain was not considered. ${ }^{4} \mathrm{CXbd} 1$ Haplic cambisol, typically dystrophic, clayish texture, subtropical field phase. ${ }^{5} \mathrm{CXbd} 3$ - Haplic cambisol, typically dystrophic, average texture, humid subtropical field phase (BHERING et al., 2008).

As presented in figure 2, from each tree, two wood discs were extracted, approximately $5 \mathrm{~cm}$ thick, being one taken exactly at diameter at breast height-DBH $(1.30 \mathrm{~m}$ from the ground) and another right above this position (1.35 $\mathrm{m}$ from the ground). Basic density of wood was obtained from $45^{\circ}$ wedges, taken from discs extracted right above DBH, from recently felled trees. Basic density was calculated from the mean of three test samples, measuring $1.5 \times 2.0 \mathrm{~cm}$, of the transversal section in the longitudinal direction, extracted in equidistant positions (pith, center and periphery) in the radial direction of DBH disc.

FLORESTA, Curitiba, PR, v. 45, n. 1, p. 193 - 202, jan. / mar. 2015.

Mauri, R. et al.

ISSN eletrônico 1982-4688 / ISSN impresso 0015-3826

DOI: $10.5380 /$ rf.v45i1.34114 


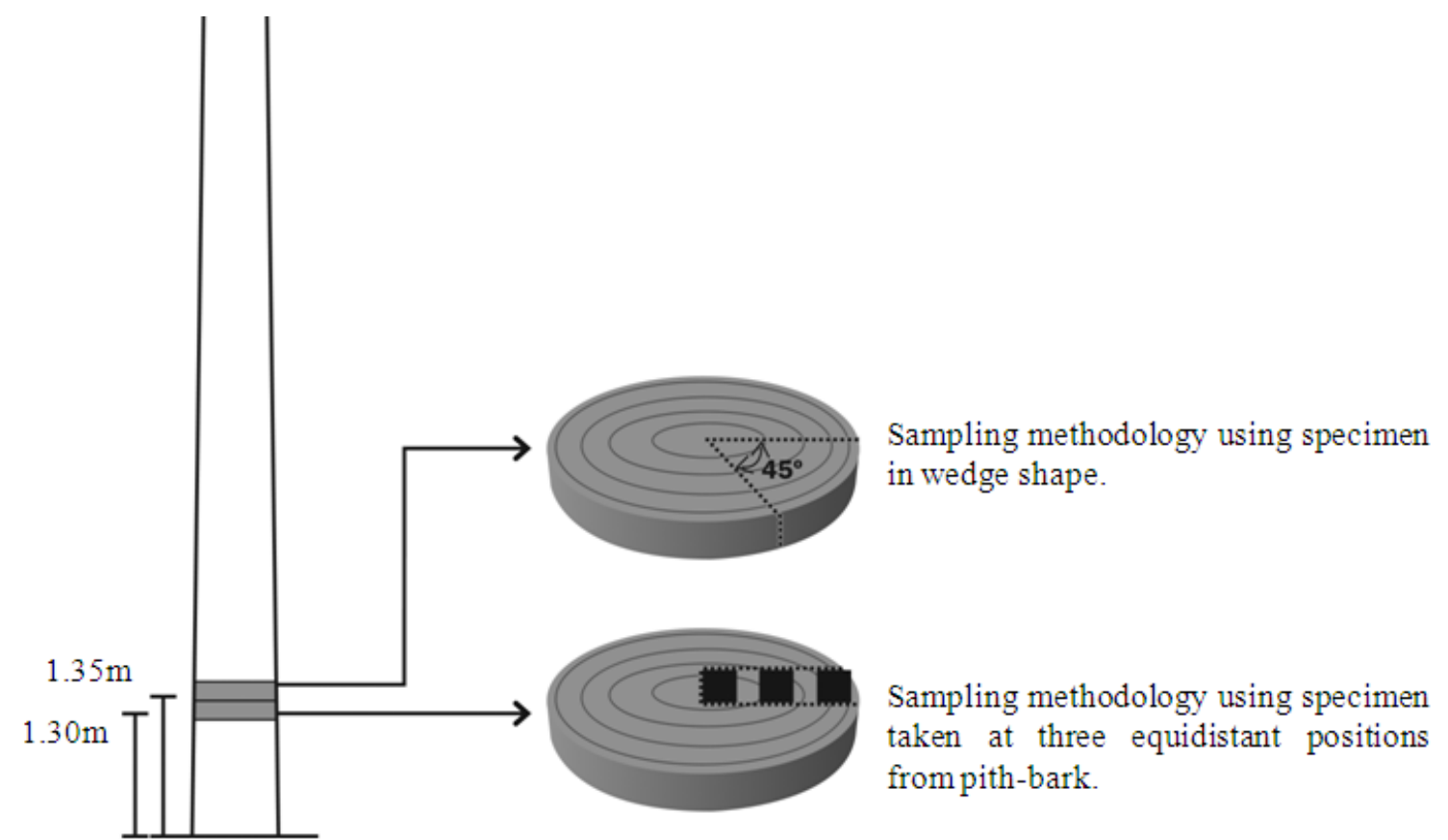

Figure 2. Sampling scheme of discs in the trees and location of the test samples.

Figura 2. Esquema de amostragem dos discos nas árvores e localização dos corpos de prova.

For both the sampling methodologies (wedge and three equidistant positions), basic density was calculated by the water immersion method NBR 11941 (ABNT, 2003).

For both sampling methods, a completely randomized design (CRD) was adopted. Program R ( R version 2.14.2) was used for the statistical analysis, performing analysis of variance, and once significance was identified, Tuckey HSD test was applied to verify differences at $1 \%$ of significance.

\section{RESULTS AND DISCUSSION}

\section{Area of DBH cross-section}

In table 2 is possible to notice that there was variation in the area of cross-section between clones of the high region only, with clone 1 presenting greatest values, probably due to genetic superiority of clone 1 to adapt to these growth conditions. Considering variations of cross-section area of the disc inside the clone, it is observable that, independently on clone and region, there was no significant difference in terms of cross-section area of the disc between plane and inclined topography.

Resuming, to measure cross-section area of a wood disc means to measure the area occupied by cells forming this disc. Thus, comparing the cross-section area of DAP, we are on the right path to compare the mean cell enlargement of DAP. This way, lack of statistical difference between topographies may be explained by the fact that cell enlargement depends mainly on xylem water potential (KOZOLOWSKI; PALLARDY, 1997, KRAMER, 1987), which is the primary cause of cell growth. Since xylem water potential is a function of water equilibrium in soil (DELEUZE; HOULLIER, 1998), one may suppose that difference between plain and inclined soil in this work, in terms of water availability, was not big enough to modify significantly the cell enlargement. Even though, one may notice that bigger values in the cross-section area of the disc are observed in plain topography, indicating influence of hydric deficit on enlargement of the cambial initials cells. 
Table 2. Average values of cross-section área of DBH and statistics between clones and growth conditions.

Tabela 2. Valores médios da área da sessão transversal do DAP e estatísticas entre clones e condições de crescimento.

\begin{tabular}{lcc}
\hline \multirow{2}{*}{ Growth condition } & \multicolumn{2}{c}{ DBH cross-section $\left.\mathbf{( c m}^{\mathbf{2}}\right)$} \\
\cline { 2 - 3 } & Clone $\mathbf{1}$ & Clone 2 \\
\hline Low/Inclined & $188.53 \mathrm{~A}^{*} \mathrm{a} *$ & $161.84 \mathrm{~A} \mathrm{a}$ \\
& $(34.33 ; 18.21)^{1}$ & $(24.49 ; 16.13)$ \\
Low/Plain & $207.97 \mathrm{~A} \mathrm{a}$ & $199.34 \mathrm{~A} \mathrm{a}$ \\
& $(24.88 ; 11.97)$ & $(5.53 ; 2.78)$ \\
High/Inclined & $212.65 \mathrm{~A} \mathrm{a}$ & $153.16 \mathrm{~B} \mathrm{a}$ \\
& $(25.44 ; 11.91)$ & $(20.19 ; 13.18)$ \\
High/Plain & $213.37 \mathrm{~A} \mathrm{a}$ & $162.23 \mathrm{~B} \mathrm{a}$ \\
& $(29.24 ; 13.77)$ & $(15.05 ; 9.28)$
\end{tabular}

*Means followed by the same uppercase letter in the line are not statistically different by the test of Tuckey at $1 \%$ of significance. ** Means followed by the same lowercase letter in the column are not statistically different by the test of Tuckey at $1 \%$ of significance. 1 Values referred to standard deviation $(\mathrm{g} / \mathrm{cm} 3)$ and coefficient of variation $(\%)$, respectively.

\section{Basic density (Wedge)}

In table 3, should be noted that there was no variation in wood basic density between clones. Considering basic density variation within the clone, it is possible to notice that, independently from clones, low region did not show significant difference between plain and inclined topography. However, in the high region, both clones showed statistically significant difference between topographies, being the biggest density values found in the plain topography. Density values found in this study are similar to results found by Duarte (2007), who, studying hybrid Eucalyptus urophylla x E. grandisbetween 5 and 6 years old,original from three distinct regions, found basic density values from 0.46 to $0.48 \mathrm{~g} / \mathrm{cm}^{3}$.

Table 3. Average values of wood specific gravity (wedge)and statisticsbetween clones and growth conditions.

Tabela 3. Valores médios da densidade básica da madeira (cunha) e estatísticas entre clones e condições de crescimento.

\begin{tabular}{lcc}
\hline \multirow{2}{*}{ Growth conditions } & \multicolumn{2}{c}{ Basic density $\mathbf{( g / \mathbf { c m } ^ { \mathbf { 3 } } )}$} \\
\cline { 2 - 3 } & Clone 1 & Clone 2 \\
\hline Low/Inclined & $0,490 \mathrm{~A}^{*} \mathrm{a}^{* *}$ & $0,474 \mathrm{~A} \mathrm{~b}$ \\
& $(0,014 / 2,83)^{1}$ & $(0,012 / 2,61)$ \\
\cline { 2 - 3 } Low/Plain & $0,477 \mathrm{~A} \mathrm{a}$ & $0,466 \mathrm{~A} \mathrm{~b}$ \\
& $(0,007 / 1,50)$ & $(0,012 / 2,49)$ \\
High/Inclined & $0,447 \mathrm{~A} \mathrm{~b}$ & $0,464 \mathrm{~A} \mathrm{~b}$ \\
& $(0,014 / 3,12)$ & $(0,010 / 2,53)$ \\
High/Plain & $0,501 \mathrm{~A} \mathrm{a}$ & $0,490 \mathrm{~A} \mathrm{a}$ \\
& $(0,012 / 2,47)$ & $(0,004 / 0,84)$ \\
\hline
\end{tabular}

*Means followed by the same uppercase letter in the line are not statistically different among them by the test of Tuckey at $1 \%$ of significance. ${ }^{* *}$ Means followed by the same lowercase letter in the column are not statistically different among them by the test of Tuckey at $1 \%$ of significance. 1 Values referred to standard deviation $(\mathrm{g} / \mathrm{cm} 3)$ and coefficient of variation (\%) respectively.

As was demonstrated by Vasconcelos Dias and Cláudio da Silva Jr (1985), increase of wood density is strongly and positively correlated to increase in cell walls thickness and decrease of fibers diameter. Thus, statistical differentiation of basic density between plain and inclined topographies for both clones, in the high region, may be explained by thickness of the secondary cell wall of fibers. This is why, in this study, the effect of cellular diameter over wood density can be ignored, since DBH crosssection area, in other words the mean cell diameter, was not statistically different between topographies. This way, considering a parsimonious vision of thickening of the secondary cell wall in fibers as if it was depending only on availability of photosynthates, which are its main growing factor (DREW et al., 2010; DELEUZE; HOULLIER, 1998), lower wood basic density, observed in the inclined topography, occurs in function of the angle of incidence of the sunrays. In fact, this topography causes reduction of the daily

FLORESTA, Curitiba, PR, v. 45, n. 1, p. 193 - 202, jan. / mar. 2015.

Mauri, R. et al.

ISSN eletrônico 1982-4688 / ISSN impresso 0015-3826

197

DOI: $10.5380 /$ rf.v45i1.34114 
direct incidence period (PEREIRA et al., 2002), and, as consequence, lower production of photosynthates.

Lack of statistical differentiation of basic density between plain and inclined topographies for both clones, in the low region, was probably caused by interaction of edaphic and climatic factors. It is supposed that soil of the lower region was more appropriate and acted as compensation of the reduced daily period of direct incidence of the sunrays.

These results show that, even with high genetic heritability of wood density (OTEGBEYE; KELLISON, 1980; KAGEYAMA; VENCOVSKY, 1983), influence of growth conditions plays an important role on its development. This contradicts the affirmation of Moraes (1987), who declared low genotype $\mathrm{x}$ environment interaction of wood basic density.

In relative terms, basic density of the high/plain region was, on average, $8 \%$ bigger than in the high/inclined area. This result is very important for industry, since basic density is strictly related to contraction and swelling (JANKOWSY, 1979), mechanical resistance (MALAN, 1988), to yield and quality of pulp (BARRICHELLO et al., 1980), to charcoal production and quality (VALENTE, 1986), and to operational costs related to transportation and stocking (SLOOTEN, 1977).

This said, study of genotype $\mathrm{x}$ environment interaction is very important for various management decisions like, for example, deciding which are the best areas to buy for planting; estimate forest productivity in terms of dry mass quantity per hectare; and as support to the economic assessment of the forest.

To make statistical comparison between regions, effect of topography was eliminated.

Table 4. Analysis of variance about the effect of altitude on wood specific gravity.

Tabela 4. Análise de variância sobre o efeito da altitude na densidade básica da madeira.

\begin{tabular}{lccccc}
\hline F.V. & G.L. & S.Q. & Q.M. & F & p-value \\
\hline Treatments & 3 & 0.001 & 0.0003 & 0.906 & 0.448 \\
Residuals & 36 & 0.013 & 0.0004 & & \\
\hline Total & 39 & 0.014 & & & \\
\hline
\end{tabular}

According to the analysis of variance presented on table 4 , there is no statistical difference between treatments considering a nominal value of $1 \%$ of significance, in other words wood basic density did not suffer influence of altitude.

This result is similar to what obtained by Brasil and Vega (1994), who studied basic density of Eucalyptus urophylla wood, growing at altitudes of approximately $50 \mathrm{~m}$ (Linhares, ES) and $280 \mathrm{~m}$ (Belo Oriente, MG), and found similar behavior of basic densities in the two grove sites.

\section{Basic density ( 3 positions)}

According to table 5, variation of basic density between clones was observed in the low/inclined growth condition, where there were bigger density values for clone 1 . Considering variation within the clone, it should be noticed for both clones and regions that plain topography has tendency to present greater basic density values, however, just clone 2 gave statistically different results in the low region and only clone 2 gave different results in the high region. Discussions carried on about basic density variation measured in the wedge shaped specimen are valid in this topic.

Considering comparison between regions, the effect of soil topography was eliminated. Mean value of basic density for clone 1 was 0.477 and $0.454 \mathrm{~g} / \mathrm{cm}^{3}$, respectively for low and high regions. Mean value of basic density for clone 2 was 0.448 and $0.475 \mathrm{~g} / \mathrm{cm}^{2}$, respectively for low and high regions. 
Tabela 5. Valores médios da densidade básica da madeira determinados em três posições equidistantes (medula, centro e periferia) no discoe estatísticas entre clones e condições de crescimento.

Table 5. Average values of wood specific gravity density determined in three equidistant positions (pith, center and periphery) of the discand statisticsbetween clones and growth conditions.

\begin{tabular}{lcc}
\hline \multirow{2}{*}{ Growth condition } & \multicolumn{2}{c}{ Basic Density $\left(\mathbf{g} / \mathbf{c m}^{\mathbf{3}}\right)$} \\
\cline { 2 - 3 } Low/Inclined & $0.474 \mathrm{~A}^{*} \mathrm{a}^{* *}$ & Clone 2 \\
Low/Plain & $(0.023 / 6.29)^{1}$ & $0.440 \mathrm{~B} \mathrm{~b}$ \\
& $0.480 \mathrm{~A} \mathrm{a}$ & $(0.016 / 3.67)$ \\
High/Inclined & $(0.026 / 5.37)$ & $0.455 \mathrm{~A} \mathrm{a}$ \\
& $0.430 \mathrm{~B} \mathrm{~b}$ & $(0.004 / 0.86)$ \\
High/Plain & $(0.010 / 2.33)$ & $0.467 \mathrm{~A} \mathrm{a}$ \\
& $0.479 \mathrm{~A} \mathrm{a}$ & $(0.013 / 2.84)$ \\
& $(0.019 / 4.06)$ & $0.483 \mathrm{~A} \mathrm{a}$ \\
\end{tabular}

*Means followed by the same uppercase letter in line are not statistically different by the test of Tuckey at $1 \%$ of significance. **Means followed by the same lowercase letter in column are not statistically different by the test of Tuckey at $1 \%$ of significance.

${ }^{1}$ Values referred to standard deviation $\left(\mathrm{g} / \mathrm{cm}^{3}\right)$ and coefficient of variation $(\%)$, respectively.

Considering analysis of variance presented in tables 6 and 7, it should be noticed that only clone 2 showed statistically significant differences between treatments, considering a nominal significance value of $1 \%$, being the greatest basic density values found in the high region.

Tabela 6. Análise de variância (clone 1) sobre o efeito da altitude na densidade básica da madeira.

Table 6. Analysis of variance ( clone 1) about the effect of altitude on wood specific gravity.

\begin{tabular}{lccccc}
\hline F.V. & G.L. & S.Q. & Q.M. & F & p-value \\
\hline Treatments & 1 & 0.003 & 0.003 & 3.215 & 0.090 \\
Ressiduals & 18 & 0.014 & 0.001 & & \\
\hline Total & 19 & 0.017 & & & \\
\hline
\end{tabular}

Table 7. Analysis of variance ( clone 2) about the effect of altitude on wood specific gravity.

Tabela 7. Análise de variância (clone 2) sobre o efeito da altitude na densidade básica da madeira.

\begin{tabular}{lccccc}
\hline F.V. & G.L. & S.Q. & Q.M. & F & p-value \\
\hline Treatments & 3 & 0.004 & 0.004 & 17.322 & 0.001 \\
Residuals & 36 & 0.004 & 0.0002 & & \\
\hline Total & 39 & 0.008 & & & \\
\hline
\end{tabular}

Variations of density found in clones 2 are divergent from the study performed by Ribeiro and Zani FIlho (1993) who, analyzing edaphoclimatic variations between sampling regions concluded that with better edaphoclimatic conditions there is a decrease in basic density of Eucalyptus grandis wood. It is worth to highlight that clone 1 presented the same tendency verified by the authors, however without statistically significant difference. These results evince the complexity involved in formation of secondary xylem and of the adaptive strategies taken by species.

\section{Comparison between sampling methodologies}

Comparing results presented in table 3 and table 5, was noted that there was variation in value of basic density between sampling methodologies of the disc (wedge and 3 equidistant positions in radial direction). This is probably due to specimen geometry. The wedge shaped specimen returns sampling in a way that wood produced in different growth seasons is collected proportionally, being thus a representative sample of the disc; meanwhile the systematic sampling in 3 positions would not satisfy just as well this density variation of the disc. Lower values in standard deviation and coefficient of variation in wedge shaped specimen highlight its superiority as specimen to estimate average basic density of wood in the disc. Besides being more accurate, wedge shaped specimen is more practical because takes less time to be prepared. 
Best accuracy together with practicality makes the wedge shaped specimen the most efficient sampling method in order to estimate basic density of the disc.

\section{CONCLUSIONS}

According with the results obtained, the following conclusions were achieved:

- Greatest density values were observed in plain topography

- There is the same tendency of wood basic density variation in clones, even in different growth conditions.

- There was no unique variation tendency of wood density (sampling in 3 positions) for the clones, related to the studied heights.

- Disc sampling method has influence on the calculated value of basic density.

\section{REFERENCES}

ASSOCIAÇÃO BRASILEIRA DE NORMAS TÉCNICAS (ABNT). Madeira: determinação da densidade básica - NBR 11941. Rio de Janeiro: ABNT, 2003. 6 p.

ASSOCIAÇÃO BRASILEIRA DE PRODUTORES DE FLORESTAS PLANTADAS (ABRAF). Anuário estatístico ABRAF 2013 ano base 2012.Disponível em:<http://www.abraflor.org.br/estatisticas /ABRAF13/ABRAF13_BR.pdf>. Acesso em: 23/10/2013.

BAPTISTA, V. R.; CARNEIRO TOMAZELLO, M. G.; TOMAZELLO FILHO, M. Caracterização da madeira de eucaliptos: anatomia, densidade básica e densitometria de raios-X. Disponível em: <http://143.107.70.222/informa/floresta.html>. Acesso em: 19/08/2003.

BARRICHELO, L. E. G.; BRITO, J. O.; COUTO, H. T. Z.; CAMPINHOS JÚNIOR, E. Densidade básica, teor de holocelulose e rendimento em celulose da madeira de Eucalyptus grandis. In: SIMPÓSIO IUFRO EM MELHORAMENTO GENÉTICO E PRODUTIVIDADE DE ESPÉCIES FLORESTAIS DE RÁPIDO CRESCIMENTO, 2.,1980, Águas de São Pedro. Anais do... Águas de São Pedro, 1980. p. 802.

BARRICHELO, L. E. G.; BRITO, J. O.; MIGLIORINI, A. J. Estudo da variação longitudinal da densidade básica de Eucalyptus spp. In: $4^{\circ}$ CONGRESSO FLORESTAL BRASILEIRO, 2., 1983, São Paulo. Anais do... São Paulo, 1983. p. 726.

BAAS, P. The wood anatomical range in Ilex (Aquifoliacea) and its ecological and phylogenetic significance. Blumea, Leiden, v. 21, p. 193 - 258, 1973.

BASSA, A. G. M. C.; SILVA JUNIOR; F. G.; SACON, V. M. Misturas de madeira de Eucalyptus grandis $x$ Eucalyptus urophylla e Pinus taeda para produção de celulose kraft através do Processo LoSolids®. Scientia Florestalis, v. 51, n. 75, p. 19 - 29, 2007.

BHERING, S. B.; SANTOS, H. G. dos; BOGNOLA, I. A.; CURCIO, G. R.; MANZATTO, C. V.; CARVALHO JÚNIOR, W. de; CHAGAS, C. da S.; ÁGLIO, L. D.; SOUZA, J. S. de. Mapa de solos do Estado do Paraná: legenda atualizada. Rio de Janeiro: EMBRAPA Florestas \& EMBRAPA Solos \& IAPAR, 2008. 74 p.

BRASIL, M. A. M.; VEIGA, R. A. A. Variation on wood basic density of Eucalyptus urophylla S. T. Blake progenies attwo sites. Ciência Florestal, Santa Maria, RS, v. 4, n. 1, p. 167 - 174, 1994.

DELEUZE, C.; HOULLIER, F. A simple process-based xylem growth model for describing wood microdensitometric profiles. Journal of Theoretical Biology. v. 193, n. 9, p. 99 - 113, 1998.

DREW, D. M.; DOWNES, G. M.; BATTAGLIA, M. Cambium, a process-based model of daily xylem development in Eucalyptus. Journal of Theoretical Biology. v. 264, n. 22, p. 395 - 406, 2010.

DUARTE, F. A. S. Avaliação da madeira de Betula pendula, Eucalyptus globus e do híbrido de Eucalyptus grandis $\mathbf{x}$ urophylla destinadas à produção de polpa celulósica Kraft. $107 \mathrm{f}$. Dissertação (Mestrado em Ciências Florestais) - Escola Superior de Agricultura "Luiz de Queiroz", Piracicaba, 2007. 
GONÇALVES, F. G. Efeito da taxa de crescimento na qualidade da madeira de híbrido clonal de Eucalyptus urophylla $\mathbf{x}$ grandis para produtos sólidos. 167 f. Dissertação (Mestrado em Produção Vegetal) - Universidade Federal do Espírito Santo, Alegre, 2006.

JANKOWSKY, I. P. Madeira juvenil, formação e aproveitamento industrial. IPEF, Piracicaba, n. 81, p. 1 - 18 , 1979.

KAGEYAMA, P. Y.; VENCOVSKY, R. Variação genética em progênies de uma população Eucalyptus grandis Hill ex Maiden. IPEF, Piracicaba, n. 24, p. 9 - 26, 1983.

KOZlOWSKI, T. T.; PALlaRDY, S. G. Growth Control in Wood Plants. San Diego: Academic Press, 1997. 640 p.

KRAMER, P. J. The role of water stress in tree growth.Journal Arboric. v. 13, n. 2, p. 33 - 38, 1987.

MALAN, F. S. Genetic variation in some growth and wood properties among 18 fullsib families of South African grown Eucalyptus grandis: a preliminary investigation. South African Forestry Journal, n. 146, p. $38-43,1988$.

METCALFE, C. R.; CHALK, L. Anatomy of the dicotyledons. Oxford: Clarendon Press, 1950. v. 1, 806 p.

METCALFE, C. R.; CHALK, L. Anatomy of the dicotyledons. Oxford: Clarendon Press, 1983. v. 2, 308 p.

MORA, A. L.; VALERI, S. V.; FERREIRA. M.; KAGEYAMA, P. Y. Bases para o melhoramento genético da densidade básica da madeira de Eucalyptus grandis. IPEF, Piracicaba, v. 6, n. 19, p. 53 - 61, 1978.

MORAES, M. L. T. Variação genética da densidade básica da madeira em progênies de Eucalyptus grandis Hill ex Maiden e suas relações com as características de crescimento.115 f. Dissertação (Mestrado em Ciências Florestais) - Escola Superior de Agricultura "Luiz de Queiroz”, Piracicaba, 1987.

OLIVEIRA, J. T. S.; HELLMEISTER, J. C.; TOMAZELLO FILHO, M. Variação do teor de umidade e da densidade básica na madeira de sete espécies de eucalipto. Revista Árvore,Viçosa, MG, v. 29, n. 1, p. $115-127,2005$.

OTEGBEYE, G. O.; KELLISON, R. C. Genetics of wood bark characteristics of Eucalyptus viminalis. Silva e Genetica, v. 29, n. 1, p. 27 - 31, 1980.

PEREIRA, A. R.; ANGELOCCI, L. R.; SENTELHAS, P. C. Agrometeorologia - fundamentos e aplicações práticas. Guaíba: Ed. Agropecuária, 2002. 478 p.

R DEVELOPMENT CORE TEAM. R:a language and environment for statistical computing. Vienna. Disponível em:<http://www.r-project.org> Acesso em:29/04/20012.

RIBEIRO, F. A.; ZANI FILHO, J. Variação da densidade básica da madeira em espécies/ procedências de Eucalyptus spp. IPEF, Piracicaba, v. 46, p. 76 - 85, 1993.

SILVA, J. C.; OLIVEIRA, J. T. S.; TOMAZELLO FILHO, M.; KEINERT JÚNIOR, S.; MATOS, J. L. $\mathrm{M}$ de. Influência da idade e da posição radial na massa específica básica da madeira de Eucalyptus grandis Hill ex. Maiden. Revista Floresta, Curitiba, PR, v. 34, n. 1, p. 13 - 22, 2004.

SHIMOYAMA, V. R. S. Variações da densidade básica e características anatômicas e químicas da madeira em Eucalyptus sp. 93 f. Dissertação (Mestrado em Engenharia Florestal)-Escola Superior de Agricultura "Luiz de Queiroz", Piracicaba, 1991.

SLOOTEN, H. van der. A importância da densidade da madeira na produtividade florestal. Brasília, DF: PRODEPEF, 1977. 8 p. (PRODEFEF. Comunicação técnica, 13).

TOMAZELLO FILHO, M. Variação radial da densidade básica e da estrutura anatômica da madeira de $E$. saligna e E. grandis. IPEF, Piracicaba, n. 29, p. 37 - 45, 1985.

TREVISAN, R.; HASELEIN, C. R.; MELO, R. R.; STANGERLIN, D. M.; BELTRAME, R.; GATTO, D. A.; CALEGARI, L. Variação radial da massa específica básica da madeira Eucalyptus grandis W. Hill ex Maiden. Revista Floresta, Curitiba, PR, v. 38, p. 553 - 559, 2008.

FLORESTA, Curitiba, PR, v. 45, n. 1, p. 193 - 202, jan. / mar. 2015.

Mauri, R. et al.

ISSN eletrônico 1982-4688 / ISSN impresso 0015-3826

DOI: $10.5380 /$ rf.v45i1.34114 
TRIANOSKI, R.; MATOS, J. L. M.; IWAKIRI, S.; PRATA, J. G. Variação longitudinal da densidade básica da madeira de espécies de pinus tropicais. Revista Floresta, Curitiba, PR, v. 43, n. 3, p. 503 - 510, 2013.

VALENTE, U. F. Carbonização da madeira de eucalipto. Informe Agropecuário. Belo Horizonte, v. 12, n. 141, p. 74 - 77, 1986.

VASCONCELOS DIAS, R. L.; CLAUDIO-DA-SILVA JÚNIOR, E. A influência da densidade básica da madeira de híbridos de Eucalyptus grandis em suas características químicas e propriedades de polpação do papel. In. CONGRESSO ANUAL DA ABTCP - semana do papel, 1985, São Paulo. Anais do... São Paulo, 1985. p. 35 - 55. 